\title{
65 逆浸透無菌精製水装置における手術用手洗い水の無菌状態の評価と検討
}

真茅孝志, 鶴田千之, 戸畑裕志 (久留米大病院中央手術部),

久木原 通 (久留米大医学部付属医療センター), 上田直行 (久留米大医学部麻酔科)

当手術部では，1988年 1 月より手術用手洗い水の供 給方式として常時循環型ミラー配管による逆浸透無菌 精製水装置を設置し，現在まで約 8 年間使用している.

手洗い水の無菌状態を維持するために, 毎月 1 回の 細菌検查及び装置の点検, 定期的なつィルターの交換 などの保守管理を行っている．1995年10月まで，本装 置に対して行った手洗い水細菌培養検查で極めて良好 な結果を得ている.

今回, 手洗い水細菌培差検查の対象となったのは, 2 系列の装置からそれぞれ手術部内に供給され，手術 用手洗い水として使用される隇菌水（蛇口 26 所）.

検查方法としては, 各蛇口上り毎月 1 回, 手洗い用 精製水を早朝 5 分間流水，その後 $100 \mathrm{ml}$ を採取し， 東洋䊉 coster $0.45 \mu \mathrm{m}$ フィルターを用いて検体をる
過する。

ろ過後のフィルターに東洋紡 coster 培地 (一般細 菌用 TGE Total count）を浸透させ， $35^{\circ} \mathrm{C} ， 1$ 週間 培責し，コロニーの有無を毎日確認する。

手洗い水細菌培盖検查の結果は, 1990年から1991年 の 2 年間に括いて $1 \sim 3$ ヶ所の蛇ロより，3〜 5 個の コロニーを認めることがあった。また1992年 5 月には， 4 ヶ所の蛇口より合計35個のコロニーを認めた. しか し，1992年 6 月から1995年10月までの期間には全くコ ロニーを認めていない，よって今回，本装置の特徵及 び利点とともに，1989年 1 月から1995年10月までに行 った手洗い水細菌培盖検查の結果を検討したので報告 する.

\section{6 電解酸性水による休面清拭の消毒勃果}

野口悟司, 中谷 博, 增田行雄, 中田精三, 池田卓也 (大阪大手術部), 有坂政員 (日本インテック), 山中英明（環境衛生薬品）

手術部の清掃法についてはこれまで種々の方法や薬 剂が使用されてきた. 最近, 電解酸性水の殺菌効果や 感染例に対する臨床効果の報告が見られ，耐性化が起 きにくい消毒剛の代用として注目されている。しかし， 電解酸性水の欠点としては, 有機物に反応して殺菌力 が低下しやすい点や金属腐蝕を引き起こすことがある 点, また電解酸性水の殺菌力の低下を簡単に判定でき ないことから交換時期が問題となっている，そこで， この電解酸性水を休殺菌剂として術後清掃時に使用し その有効性につき検討した，今回は，プラスチック製 の 2 バケットの清掃システムカートを用いた。 モップ
は新品のものを洗濯して糊を落とした後に蒸気滅菌を 行った. 数枚のモップをまとめて電解酸性水に浸漬し て使用した. モップはハンドル式のワンタッチ着脱で きる物で, 評価の容易な廊下の床を直線的に清拭処理 して交換した．本法での效果判定は清拭前後に $1 \mathrm{~m}$ 間 隔で床の付着菌をスタンプフガー法で採取し，48時間 培養後のコロニーを計数して行った.

電解酸性水による各処理部所の殺菌効果は対照とし て使用した塩化ベンザルコニウムと同等であり, 電解 酸性水の床面に対する殺菌効果は満足できるるのと考 えられた。 